\title{
Improved current methods for amplification of DNA from routinely processed liver tissue by PCR
}

\author{
Xavier de Lamballerie, Françoise Chapel, Catherine Vignoli, Christine Zandotti
}

\begin{abstract}
With both a classic DNA preparation protocol (including removal of paraffin wax and protein digestion) and a DNA extraction protocol with Chelex 100, the hepatitis $B$ virus genome was searched for using the polymerase chain reaction (PCR) in 30 samples of paraffin wax embedded liver tissue from patients with chronic hepatitis. The classic protocol was more sensitive than the rapid Chelex 100 procedure (10 $v$ six positive samples). A third protocol, including removal of paraffin wax, protein digestion, and Chelex 100 treatment of the digestion solution before PCR, was more sensitive than the others (16 positive samples). It is concluded that it could therefore be helpful for PCR analysis of paraffin wax embedded liver tissue.
\end{abstract}

(F Clin Pathol 1994;47:466-467)

High performance DNA preparation from paraffin wax embedded liver tissue is of major interest for identification of the hepatitis $B$ virus (HBV) genome by the polymerase chain reaction (PCR). Current methods involve removal of paraffin wax and protein digestion steps, usually with xylene and proteinase K. ${ }^{12}$ This extraction is more difficult than DNA extraction from frozen liver biopsies, and a roughly 10 -fold reduction in sensitivity has been reported when current methods are used. $^{3}$ Alternatively, a one step preparation method with Chelex 100 (Bio-RAD, Richmond, VA, USA) has recently been proposed, to reduce the time of sample preparation and the risk of contamination. Although this method was proposed for any type of paraffin wax embedded tissue, it was tested only for human cardiac valves infected with Coxiella burnetii. ${ }^{4}$

In this paper, a comparison between these methods is presented, and a combination of existing protocols is proposed for the optimisation of DNA preparation from paraffin embedded liver tissue.

\section{Methods}

Thirty samples of paraffin wax embedded liver tissue (fixed in $4 \%$ formalin) from patients with chronic hepatitis were tested with four different protocols (five slides of $7 \mu \mathrm{m}$ for each test).

The first protocol used our previously described $20 \%$ Chelex 100 suspension in a $0 \cdot 1 \%$ lauryl sulphate, $1 \%$ Nonidet P40, $1 \%$ Tween 20 aqueous solution, as recently proposed for Coxiella burnetti DNA amplification. ${ }^{5}$ Samples were boiled for 10 minutes in this solution, centrifuged, and the supernatant fluid was directly used for PCR. Final concentrations were $3 \mu \mathrm{M}$ (each) primer MDA (5')-GTTAGGGTTTAAATGTATAC and MDB (5')-ATCTTCTTATTGGTTCTTCT, $200 \mu \mathrm{M}$ (each) dATP, dCTP, dGTP and dTTP, $50 \mathrm{mM} \mathrm{KCl}, 10 \mathrm{mM}$ TRIS- $\mathrm{HCl}$ (pH 8.3), $2.2 \mathrm{mM} \mathrm{MgCl}{ }_{2}, 0.001 \%$ w/v gelatin, and $20 \mathrm{U} / \mathrm{ml}$ Thermus aquaticus polymerase (AmpliTaq, Perkin-Elmer Cetus Corp, Norwalk, CT, USA). Cycling details were: initial denaturation at $90^{\circ} \mathrm{C}$ for $10 \mathrm{~min}$ utes; 35 cycles $\left(95^{\circ} \mathrm{C}\right.$ for 30 seconds, $47^{\circ} \mathrm{C}$ for 45 seconds, $75^{\circ} \mathrm{C}$ for 45 seconds), and a final extension step at $75^{\circ} \mathrm{C}$ for 10 minutes. Products of the PCR were diluted 10 times and submitted to 20 cycles of nested PCR with comparable reacting conditions, with primers MD06 (5')-CTTGGATCCTATGGGAGTGG and MD03 (5')-CTCAAGCTTCATCATCCATATA. ${ }^{6}$ Final identification of $P C R$ products was performed with the GEN ETI K DEIA microplate assay (Sorin Biomedica, Saluggia, Italy) ${ }^{7}$ including hybridisation at $55^{\circ} \mathrm{C}$ to a specific probe, MD09 (5')-GGCCTCAGTCCGTTTCTCTTGGC. ${ }^{6}$

The second protocol included removal of paraffin with xylene and digestion of samples with proteinase $\mathrm{K}$ but no DNA extraction step, as previously described. ${ }^{3}$ Primary PCR was performed with this digestion solution. Amplification conditions were those described earlier.

In the third protocol, after removal of paraffin with xylene and digestion with proteinase K, DNA was extracted twice with phenol-chloroform and precipitated in ethanol before PCR.

In the last protocol, the removal of paraffin with xylene and proteinase $\mathrm{K}$ digestion steps were followed by Chelex 100 treatment of the digestion solution: the solution from proteinase $\mathrm{K}$ digestion was mixed with an equal volume of Chelex 100 solution, boiled for 15 minutes, centrifuged $(13500 \times \mathrm{g}$ for $10 \mathrm{~min}$ utes), and used for PCR.

Results

Six samples were positive with the first protocol and a further four samples (total 10 samples) were positive with the second protocol. 
Preparation of samples: protocols and results of HBV PCR analysis for 30 samples of paraffin embedded liver tissue fixed in $4 \%$ formalin from patients with chronic hepatitis

\begin{tabular}{lll}
\hline & Steps before PCR & Positive samples \\
\hline $\begin{array}{l}\text { Protocol I } \\
\text { Protocol II }\end{array}$ & $\begin{array}{l}\text { Chelex 100 treatment of sample } \\
\text { Xylene treatment to remove paraffin }\end{array}$ & 6 \\
Protocol III & $\begin{array}{l}\text { Proteinase K digestion } \\
\text { Xylene treatment to remove paraffin }\end{array}$ & $6+4=10$ \\
Protocol IV & $\begin{array}{l}\text { Phenose K digestion } \\
\text { Xylene treatment to remove paraffin } \\
\text { Proteinase K digestion } \\
\text { Chelex 100 extraction of DNA }\end{array}$ & $10+6=16$ \\
\hline
\end{tabular}

In the second protocol, DNA extraction after proteinase $K$ digestion did not modify the results of PCR (10 positive samples) when a classic method (extraction with phenol-chloroform and ethanol precipitation) was used. By contrast, 16 samples were positive when the extraction was performed with Chelex 100.

The table gives a summary of technical features and results.

\section{Discussion}

Samples of paraffin wax embedded liver tissue are routinely used for PCR diagnosis of hepatitis B in many departments of pathology. Positive results of PCR are of great diagnostic relevance, but the interpretation of negative results must be prudent as the sensitivity of the method is manifestly low when this kind of sample is used. ${ }^{3}$ Numerous modifications can improve this sensitivity, but preparation of DNA is the crucial one. A rapid preparation protocol, which is adapted from our previously described one step microbial DNA extraction method with Chelex 100, has been recently proposed, but not specifically tested for liver tissue or compared with current methods.

Our results enabled us to draw the following conclusions: (a), the one step DNA extraction method with Chelex 100 should not be used alone for PCR analysis of paraffin wax embedded liver tissue because its sensitivity is very low. This is consistent with the fact that, in our experience, the Chelex 100 treatment is not efficient for the extraction of DNA from most fresh or fixed solid tissues; (b), the current method involving removal of paraffin wax and protein digestion was more efficient, and its sensitivity was not modified when DNA was extracted with phenol-chloroform and precipited in ethanol before PCR; (c), a major improvement of sensitivity was obtained with a protocol including three steps before PCR - namely, removal of paraffin wax with xylene; protein digestion with proteinase $\mathrm{K}$; and DNA extraction with Chelex 100. A possible explanation for the fact that a classic DNA extraction step did not improve the sensitivity is the inactivation of Thermus aquaticus polymerase inhibitors during treatment with Chelex 100.

We believe that this simple method will be helpful for PCR analysis of paraffin wax embedded liver tissue, and possibly for PCR analysis of other such processed tissues.

We thank Georges Lebreuil and Philippe De Micco for their critical review of the study proposal.

1 Shindo M, Okuno T, Arai K, et al. Detection of hepatitis B virus DNA in paraffin-embedded liver tissues in chronic hepatitis B or non-A, non-B hepatitis using the polymerase chain reaction. Hepatology 1991;13:167-71.

2 Wright DK, Manos M. Sample preparation from paraffin embedded tissue, In: Innis MA, Gelfand DH, Sninsky JJ, White TJ, eds. PCR protocols: a guide to methods and applications. London: Academic Press; 1990:153-8.

3 Bréchot C. Polymerase chain reaction for the diagnosis of hepatitis B and C viral hepatitis. $\mathcal{F}$ Hepatol 1992;17(suppl 3):35-41.

4 Stein A, Raoult D. A simple method for DNA amplification from paraffin-embedded tissues. Nucleic Acids Res 1992;19:5237-8.

5 de Lamballerie X, Guignolle-Vignoli C, Zandotti C, Bolle C, de Micco P. A one-step microbial DNA extraction method using "Chelex 100 " suitable for gene amplification. Res Microbiol 1992;143:785-90.

6 Baginski I, Ferrie A, Watson R, Mack D. Detection of hepatitis B virus, In: Innis MA, Gelfand DH, Sninsky JJ, White TJ, eds. PCR protocols: a guide to methods and applications. London: Academic Press 1990:348-55.

7 applications. London: Academic Press 1990:348-55. DNA enzyme immunoassay: general method for detecting products of polymerase chain reaction. Clin Chem ing products of 